\title{
Distilling the Information: Teach Explicit Note Taking to Help Students Learn
}

\author{
Karen A. Morgenstern \\ Brawerman Elementary School of Wilshire Boulevard Temple, USA
}

\begin{abstract}
This research-based session explores the need for explicit note taking instruction for students in upperelementary grades through high school. The benefits of taking notes by hand versus using a keyboard are also examined. Participants will learn specific note taking strategies to teach students that will benefit all types of learners.
\end{abstract}

Keywords: Notetaking; Notetaking Strategies; Metacognition; Learning Strategies; Information Literacy; Instructional Effectiveness; Elementary School Students; Elementary Education; Middle School Students; Secondary Education; Teaching Methods

\section{INTRODUCTION}

Students are expected to take notes throughout their academic career, yet they are rarely taught explicit note taking strategies that include using abbreviations, symbols, and writing like Cavemen speak ("pilgrims land Plymouth - 1620"). This crucial component of information literacy should not be neglected in the digital age. School librarians can increase their relevance to the school community by filling this void and delivering note taking instruction to students of all ages. Taking good notes helps students make meaning from information, enhances student performance in content area subjects and guards against plagiarism. This presentation begins with an overview of current research, noting that most studies about note taking instruction involve undergraduate students.

A connection between note taking by hand and brain function (the study of "haptics") is also explored, as well as the idea that taking notes on a laptop or mobile device is not as conducive to resonant learning as using pencil or pen. The current discussion of whether or not to teach cursive (handwriting) is briefly discussed.

\section{CONCLUSION}

Teachers who deliver note taking instruction should understand the importance of metacognition (student understanding of their own individual learning) in the development of note taking proficiency. Results of an online survey of $6^{\text {th }}$ grade students and their awareness of note taking strategies they use in content areas such as social studies and science are reviewed. Discussions with students should include the wide application of taking notes, from academia to every day life. Teaching students the personal nature of note taking should also be stressed. Learning to take notes is a process, similar to writing, and can take upwards of 15 years to perfect (Piolet \& Boch, 2004).

\section{REFERENCES}

Boch, F., \& Piolat, A. (2005). Note taking and learning: A summary of research. The WAC Journal, 16. Retrieved from http://wac.colostate.edu/journal/vol16/boch.pdf

Boye, A. (2012). Note-taking in the $21^{\text {st }}$ century: Tips for instructors and students. Texas Tech University Teaching, Learning and Professional Development Center. Retrieved From https://www.depts.ttu.edu/tlpdc/Resources/Teaching resources/TLPDC teaching resources/Doc uments/NotetakingWhitepaper.pdf 
The handwriting debate. (2012). National Association of State Boards of Education. Retrieved from http://www.nasbe.org/latest-news/handwriting-debate/

Mangen, A., \& Velay, J-V. (2010). Digitizing literacy: reflections on the haptics of writing advances in haptics. In Mehrdad Hosseini Zadeh (Ed.), InTech, DOI: 10.5772/8710. Retrieved from http://www.intechopen.com/books/advances-in-haptics/digitizing-literacy-reflections-on-thehaptics-of-writing

Mueller, P., \& Oppenheimer, D. (2014). The pen is mightier than the keyboard: advantages of longhand over laptop note taking. Psychological Science. Retrieved from https://www.depts.ttu.edu/tlpdc/ Resources/Teaching resources/TLPDC teaching resources/Documents/NotetakingWhitepaper.p $\underline{\mathrm{df}}$

Osborne, M. A. (n.d.) Taking notes: synthesizing information from a source [PowerPoint slides]. Retrieved from http://www.slideshare.net/maryaliceosborne/learning-to-take-notes

Swerling, C. \& Hermes, L. Stop plagiarism: teach note taking skills and strategies to second grade using an " $\mathrm{N}$ is for Note Taking" unit. Newton Schools Foundation, 2008. Retrieved from https:// supportingtechnology.wikispaces.com/file/view/N_is_for_notetaking.pdf/433239392/N_is_for_n otetaking.pdf 